\title{
20
}

\section{Transnational non-state regulatory regimes}

\author{
Natasha Tusikov
}

\section{Introduction}

What do Apple's Supplier Responsibility program, the UK-based Internet Watch Foundation and the campaign against unauthorised downloads of movies by the Motion Picture Association of America (MPAA) have in common? They are examples of transnational nonstate regulatory regimes. This type of regulation encompasses a broad array of regulatory arrangements carried out by corporate actors, nongovernmental organisations (NGOs) and civil society groups working alone or in collaboration. It is a form of meta-regulation that operates at a global level (see Grabosky, Chapter 9, this volume). Regulation in this context refers broadly to the means that guide any activity, individual or institution to behave according to formal or informal rules (Picciotto 2002: 1). Given the diversity of actors and activities making up this type of regulation, there is no standard definition for transnational non-state regulation. It can be broadly understood as non-state actors making, implementing and/or enforcing rules and standards across national borders. Transnational non-state regulation connects with theories of globalisation-most obviously regulatory globalisation (see Drahos, Chapter 15, this volume). 
Some arrangements may comprise a single company or industry, while others cut across industry sectors or involve multiple business and civil society stakeholders who represent a range of interests. Actors may employ formal legal mechanisms, such as national or international laws, as well as informal processes such as non-legally binding certification programs or codes of conducts. They may have different motivations and interests for becoming involved in regulatory endeavours and diverse goals. Participants may have profit-oriented goals, such as reducing regulatory duplication to strengthen corporate performance, or efforts may be publicly oriented to target problems such as pollution or child labour. Apple's Supplier Responsibility program, for instance, in which the company may terminate its contracts with suppliers that do not comply with its labour and environmental standards, is designed to burnish Apple's credentials as a good corporate citizen. The MPAA pressures internet firms, particularly Google, to make it more difficult for people to find and download unauthorised versions of copyrighted movies. In contrast, the Internet Watch Foundation is a non-profit organisation that works with internet firms like Google and PayPal to remove child pornography from websites around the world.

The rest of the chapter explores how transnational non-state regulation operates, particularly the ways in which non-state actors can make and enforce rules, and then outlines the challenges raised by this type of regulation. First, the chapter introduces the concept of regimes to provide a way to understand this type of regulation and then describes how non-state actors interact with states. Then the chapter outlines why transnational non-state regulation emerges before turning to discuss how non-state actors draw on varying forms of authority to regulate. Third, the chapter explores the varying degrees of involvement states may have with transnational non-state regulatory regimes. The chapter then discusses the benefits and challenges of this type of regulation before providing a brief conclusion.

\section{Regimes and states}

Given the diversity of actors, rules and interests making up the many instances of transnational non-state regulation, the concept of regimes provides a useful analytical framework. Regimes can be understood as 'the full set of actors, institutions, norms and rules' making up a particular regulatory arrangement (Eberlein and Grande 2005: 91). Scholars from 
the fields of international relations, socio-legal studies and regulatory theory employ the concept of regimes to explain the ways in which non-state actors can set and enforce rules and standards transnationally, and explore their varying interests in participating in such regimes (see, for example, Cutler et al. 1999). The concept is useful because it explicitly acknowledges the role of non-state actors and recognises that regulation may involve 'soft law' or informal governance practices, such as certification practices or industry-derived codes of conduct, along with other rule-making mechanisms such as contracts or statutory laws. As regime analysis considers the full ensemble of actors, interests and rules making up regulatory efforts, it is also valuable for tracking similarities and differences among actors' material and ideational interests in relation to the governance of a particular issue. Actors may have conflicting, sometimes irreconcilable, differences that shape the composition and function of governance arrangements. Regulation that materially benefits one party can impose costs on the other.

In terms of their scope, regimes may be considered transnational according to the reach of their rule-setting actors, the level of the rulesetting institutions, the span of the rules themselves or a combination of these factors (Mügge 2006: 179). Even though a regime may operate transnationally through the scope of its actors or rules, the regime may have distinct territorial roots or localised characteristics (Graz and Nölke 2008). These local roots may infuse a regime with characteristics that shape its character or operation. Prominent rule-making actors, for example, may all be based within the global North, creating rules that govern how transnational mining companies operate in the global South (see Dashwood 2012). Using regimes can help trace the particular historical and sociocultural contexts from which actors emerged to form particular regulatory arrangements.

From the term, it would appear that the state has very little or even no role in transnational non-state regulation. However, this is not the case. To understand the role of states in this type of regulation, it is important to outline briefly how states can strategically deploy their power through regulation. One way to consider how this occurs is through the framework of regulatory capitalism, which is prominently associated with John Braithwaite and David Levi-Faur, among other regulatory theorists (see Levi-Faur, Chapter 17, this volume). In regulatory capitalism, the state takes on a meta-regulatory role: it directs, oversees and spurs on regulation and, in so doing, governs through regulation 
(see Levi-Faur 2013). The oft-quoted metaphors of 'steering' and 'rowing' aptly describe the state's meta-regulation. In these nautical images, the state strategically 'steers' or directs regulatory efforts while non-state actors take on the state's traditional task of 'rowing' by creating and operating various regulatory arrangements (Osborne and Gaebler 1992).

States may play a strong, direct role by facilitating regulatory efforts, prescribing specific goals or mandating the use of certain monitoring and enforcement mechanisms. They may also govern indirectly by empowering non-state actors to enact rules, shaping discourse and distributing resources (Levi-Faur 2013: 39). States may also provide incentives to corporate and civil society actors to create or enforce certain rules and standards (see Gunningham and Sinclair, Chapters 8 and 40; and Grabosky, Chapter 9, this volume). When there are conflicts among actors or appeals to governments for assistance, states can arbitrate among competing non-state interests. Corporate actors, for example, may lobby a state for a particular regulatory approach that is opposed by civil society groups that advocate different measures. Not all actors have equal resources with which to persuade states to support their regulatory preferences or command the same degree of influence in shaping state policymaking processes. Some large corporate actors have the capacity to lobby for policies that benefit their interests and create their own rules and standards, both domestically and transnationally, to regulate their individual corporations, their global supply chains or even industry sectors. Similarly, not all states have equal capacity to influence, stimulate or control regulatory efforts by non-state actors, particularly mega-corporate actors.

To understand why states privilege certain interests, it is helpful to consider the state as embedded in the economic and social orders: the state and society mutually constitute one another (Underhill 2003). Simply put, there is a flow of ideas between the state and society in which each shapes the other. States grant a role in policymaking to interest groups that put forward competing and complementary ideas to articulate problems, propose remedies and shape policies. States determine which actors are more authoritative, lend legitimacy to some interests over others and privilege certain policies (Hall 1993: 288). It is important to underline that states retain interests and goals that are distinct from their lobbyists even as those actors endeavour to shape governments' priorities and policymaking. States retain a capacity to act autonomously even as they accord interest groups opportunities to shape policymaking (Hall 1993). 


\section{Origins and authority}

One of the principal reasons that non-state actors may form transnational regulatory arrangements is because states are perceived to be incapable of or unwilling to provide transnational governance on certain issues. Corporate actors or civil society groups may also turn to non-state regulation if states are not addressing problems in ways that the non-state actors consider appropriate. By creating standards and rules privately, non-state actors can work to address gaps in regulation or harmonise competing or uneven rules internationally to make governance efforts more effective (Cafaggi 2012). Multinational corporations working alongside civil society groups, for example, have created international standards in relation to the commercial use and preservation of forests (see Meidinger 2002). Similarly, child protection advocates, together with law enforcement and industry groups, created the Internet Watch Foundation to target child pornography hosted anywhere on the internet. Corporate actors may strategically embrace non-state regulation to preempt government regulation or water down existing rules (Cutler et al. 1999). There may be normative reasons for corporate actors' adoption of private rules, such as to repair or safeguard their reputations. For example, following criticism of Apple's supplychain practices, the company began using third-party auditors to ensure the tantalum, which is a valuable metal, used in its products was obtained from conflict-free countries in Africa (see Apple 2014).

Transnational non-state regulatory regimes vary widely in the sources of their authority to set or enforce rules and standards. Actors within such regimes generally exercise 'autonomous regulatory power or implemen[t] delegated power, conferred by international law or by national legislation' (Cafaggi 2010: 1). In terms of delegated authority, states may designate responsibility for monitoring or enforcing criminal or civil laws to non-state actors, or direct those actors to perform specific duties such as inspections or audits (see Scott 2002). In many countries, private security companies, such as the UK-based multinational Serco Group, have state-delegated authority to transport, guard and house prisoners. A common form of autonomous regulatory authority comes from contracts. Corporations can set rules or standards within their supply chains through contracts with their manufacturers and suppliers-for instance, in relation to labour or environmental standards (see, for example, Apple 2014). Companies that wish to become suppliers to Apple, for example, must abide by its environmental and labour 
conditions and demonstrate compliance in third-party audits or risk losing contracts. States, however, can intervene in commercial contracts if they violate laws, such as those prohibiting anticompetitive behaviour.

Non-state actors may lack a formal legal authority to govern and instead must persuade — or pressure — others to accept their rules or comply with their regulatory programs. To do so, they can draw on their resources and put forward their policies as the best approach. These are examples of structural authority and discursive authority and one may be employed to strengthen the other. Structural authority, which is based on Susan Strange's (1997) notion of structural power, refers to transnational corporate actors' capacity to influence government policymaking by threatening to relocate investment or employment. It also encompasses those actors' ability to control access to or the use of certain markets and to govern their supply chains, particularly when they dominate markets (see Fuchs and Kalfagianni 2010). Visa, MasterCard and PayPal, for example, dominate the online payment market, while Google commands the search market, which means that these companies have considerable capacity to act as online regulators. Discursive authority, in contrast, refers to actors' ability to frame and shape the meaning of ideas to affect how people understand issues and influence policymaking (Fuchs 2007). Using this capacity to shape ideas, non-state actors may also invoke moral and technical authority to argue for their preferred regulatory approach. Moral authority involves drawing broadly accepted values, while technical authority involves claims to specialised or expert knowledge or skills, or objective advice (Avant et al. 2010). The Internet Watch Foundation, for instance, claims moral authority when it demands that internet firms such as Yahoo and Google join its ranks to target the online distribution of child pornography (see Laidlaw 2012). The MPAA, meanwhile, invokes both moral and technical authority. It claims to protect the copyright of its members' movies from 'theft' ' and, invoking its status as the trade body for the movie industry, it designs policies to deter the unauthorised download of movies (see Brandom 2014).

Non-state actors without formal legal authority may create regulatory regimes based on informal measures, such as non-legally binding certification programs and corporate social responsibility codes.

1 Proponents of stronger protection for copyright have long successfully framed copyright infringement as 'theft'-an effective strategy that casts infringement as a serious crime that necessitates a correspondingly serious enforcement response (see Drahos and Braithwaite 2002). 
For example, the Forest Stewardship Council (FSC), which comprises business, social and environmental interests, certifies forestry companies, including manufacturers and retailers, as compliant with the FSC's standards on sustainability and environmental protection (see Meidinger 2002). Corporate social responsibility codes are often joint agreements between civil society organisations and corporations to address certain problems resulting from poor industry practices, such as pollution, or to improve industry practices in particular areas, such as human rights or labour standards (see Dashwood 2012). Certification and corporate social responsibility programs are generally intended to marry private business interests with public interest goals. They are designed (whether or not they are effective) to benefit the interests of the regulated, which are primarily business entities, and serve the collective interest through efforts to protect human rights, among other programs.

In addition to the arrangements described above among non-state actors, there is another that is gaining prominence: non-legally binding 'voluntary' agreements (see Gunningham and Sinclair, Chapters 8 and 40 , this volume). These agreements are voluntary in the sense that they are not based on legislation or legal contracts but on nonbinding guidelines or sets of industry-derived 'best practices'. The term 'voluntary', however, can be misleading, as states can exert considerable coercive pressure to force non-state actors to join the arrangements or abide by their decisions. Other non-state actors may also pressure stakeholders to join the agreements by threatening legal action or withholding business deals. Non-legally binding agreements are increasingly used to regulate digital copyright infringement (for example, unauthorised downloads of music and movies) and the online sale of counterfeit goods, which is a form of trademark infringement. In these nonbinding agreements, rightsholders of intellectual property - typically large multinational companies such as Nike or Sony - work with internet firms such as PayPal to stop the online distribution of copyright-infringing and counterfeit goods (Tusikov 2016).

\section{Degrees of state involvement}

Government involvement in transnational non-state regulation varies according to the issue under regulation, the nature of the regulatory arrangement and the degree of reliance, if any, on the state. As discussed earlier in the chapter, states retain the authority in the regulatory 
capitalist framework to mandate, shape, endorse or reject non-state regulatory efforts, as well as to delegate authority to non-state actors (see Levi-Faur 2013; Levi-Faur, Chapter 17, this volume). States may not necessarily be aware of or equally attentive to all cases of non-state regulation, particularly where its interests are not affected or private actors do not seek state involvement. For example, corporate social responsibility programs organised among corporations and NGOs to strengthen standards relating to environmental protection may not elicit attention from governments. As well, states vary widely in their capacity to influence and their degree of involvement in transnational non-state regulation.

Transnational non-state regulatory regimes may have little, if any, state involvement. Where there is relative agreement among stakeholders in relation to the regime, or if there are suitable incentives offered (or penalties credibly threatened), there may be few interactions with state actors. This is the case when powerful multinational companies, such as Walmart or Apple, contractually require their suppliers to adhere to specific environmental, labour or quality-control standards. Suppliers are under considerable pressure to accept these contracts as they have few alternatives given the significant market share commanded by Walmart and Apple. Further, the penalties for violation are serious. Suppliers found to be in violation of the contracts can be terminated as preferred suppliers and, given the market dominance of such firms, this means the suppliers essentially lose their licence 'to participate in the global market' (Fuchs and Kalfagianni 2010: 3). Contract-based regimes require little direct interaction with the state, as the corporations set and enforce rules through their supply chains. However, corporations' use of legal contracts to enforce rules and standards means they rely indirectly on state legal systems. Similarly, in the case of a disagreement among regime participants, actors have recourse to pursue the matter in the relevant national legal jurisdiction.

When non-state actors lack a contractual or statutory basis to their regime, they can attempt to persuade or pressure others to conform to their rules. They can draw on their structural and discursive authority by employing litigation or promising to grant or withhold business deals. If these methods fail, actors may turn to the state or its structures, although actors may have different preferences as to the degree and nature of state involvement (Cafaggi 2010). Faced with noncompliant actors, a regime's actors can, in some situations, turn to national laws or public institutions to seek compliance or use the threat of civil or criminal 
remedies to motivate compliance with the regime's rules, standards or codes. They may also seek direct assistance from state actors. Members of a transnational regime may lobby states to support or facilitate a particular regulatory agenda, or to prod reluctant actors into cooperating with the regime. The success of these requests depends on the state's interests in the regime, as well as the state's capacity and willingness to intervene. The distribution of power among non-state actors, however, is temporal as interests may shift over time or different sets of actors may assume greater power (see Downie, Chapter 19; and Halliday, Chapter 18 , this volume). Further, the state may weaken or revoke its recognition of the regulatory arrangement, non-state actors can lose credibility from their stakeholders or those they govern and rivals may contest the regime's legitimacy (Avant et al. 2010).

Some requests for state assistance resonate with the state or align more closely than others with its interests. Both the Internet Watch Foundation and the MPAA enjoy a close relationship with the UK and US governments, respectively. The UK Government is strongly supportive of the Internet Watch Foundation's enforcement strategy in which internet firms, including Google, Yahoo, Twitter and PayPal, block access to websites suspected of hosting child pornography content to deter individuals from accessing those websites (see Internet Watch Foundation 2013). Similarly, the MPAA has a long, successful history of shaping US-and international-policymaking in relation to the ever-increasing protection of copyright (see Brandom 2014; Drahos and Braithwaite 2002). For Apple, in contrast, pressure to improve the company's labour and environmental standards came primarily from NGOs and its customers (Apple Press Info 2012). In cases where states have interests in the subject of regulation, they may exert direct, even coercive, pressure on non-state actors to convince them to participate in transnational non-state regulatory regimes. For example, in the United States and the United Kingdom, government officials warned internet firms that they could expect legislation or legal action to force their compliance if they did not adopt non-legally binding agreements with rights-holders to address the online distribution of copyright-infringing and counterfeit goods (Tusikov 2016). Given this coercion, the nonlegally binding agreements are not voluntary but a form of enforced regulation. When state actors intervene in non-state regulation by supporting, facilitating or even directly creating a particular regulatory arrangement, they legitimise the authority of the non-state actors to govern and the regime. 


\section{Benefits and challenges of transnational non-state regulation}

Transnational non-state regulation can offer certain benefits (see Chang and Grabosky, Chapter 31, this volume). Governments may perceive non-state actors, particularly corporations, as more responsive, costeffective and efficient regulators than government agencies in certain areas, or as having specialised technical knowledge, industry or sector familiarity and greater access to markets (see Cutler et al. 1999). Such regulation can be more responsive and adaptive to changes in technology or circumstances than legislation, international law or trade agreements (Cafaggi 2012). As contracts and non-legally binding agreements can be more flexible than law, non-state actors may be more willing to join regulatory arrangements using these mechanisms as they may have more of an ability to provide input or amend them to suit their needs. The regime can be expanded or contracted as needed and its rules amended to reflect changing circumstances or stakeholders' needs. NGOs and civil society organisations can have greater power to push corporate - or even state- actors to address public-oriented goals, such as protection of the environment or consumers' rights, through nonstate regulatory regimes. This is particularly the case when civil society actors can capitalise on corporations' fear of scandal and damage to their reputations, as was the case with Apple and criticism of its labour practices (see Apple Press Info 2012).

Working outside more traditional legal processes can enable non-state actors to address problems that states are unwilling to or incapable of addressing alone, at least in ways that non-state actors may prefer. For example, partnerships with internet firms based on nonbinding agreements enable the MPAA and Internet Watch Foundation to extend their enforcement reach globally through the internet firms' global operations. Working with government officials from various jurisdictions using their national laws would be much more timeconsuming and difficult. Transnational non-state regulation can also provide ways to harmonise rules and address gaps or inconsistencies in national laws (see Cafaggi 2010). Non-state efforts in the forestry and food industries attempt to address these problems through the use of industry certification programs and supply-chain contracts (see Fuchs and Kalfagianni 2010; Meidinger 2002). Although non-state regulation 
is often associated with soft law, such as certification programs, it can deliver formidable sanctions. Suppliers who violate their supply-chain agreements, for example, can lose lucrative contracts.

For states, transnational non-state regulation can be useful as it enables them to reach beyond their traditional jurisdictional boundaries or to regulate in ways, or at a scale, that are typically unfeasible for government agencies. By supporting or facilitating non-state regulation, states can capitalise on or influence the production, implementation and enforcement of rules in particular sectors or issues that align with their interests. Non-state regulation can also provide avenues for states to sidestep failed, stalled, unworkable or controversial legislation or trade agreements and achieve similar, or even enhanced, regulatory outcomes. States can publicly, but selectively, endorse specific efforts or strategically distance themselves by emphasising the central role of non-state actors in the creation and operation of the regulatory regime.

Transnational non-state regulatory regimes raise significant challenges, particularly in terms of accountability and due process. In terms of accountability, it is often difficult for those outside the regime to determine how rules and standards are drafted, the ways they are enforced or by whom. It may also be difficult to evaluate the regime's effectiveness in the context of its goals. Regimes may seek to address these problems by publishing annual reports on their activities and achievements (see, for example, Apple 2014; Internet Watch Foundation 2013). These reports, however, are often little more than public relations documents that promote the regimes but do not provide the level of detail necessary to evaluate their operation or performance.

Transnational non-state regimes also raise broader challenges in terms of accountability (see Dowdle, Chapter 12, this volume). These regimes often reveal global North-South patterns in which influence over governance is concentrated in the global North. Regulatory capitalism tends to describe regimes that are shaped in North America and Europe [and] are increasingly internationalised and projected globally' (Levi-Faur 2005: 13). This means rules and standards that are generally set in the global North extend internationally to govern people who may have little awareness of the regime's existence. Further, governments in the countries in which the regimes operate may have little knowledge of or influence over these regimes, even though their governance could affect them. This pattern is echoed in the cases of Apple, the MPAA and the Internet Watch Foundation. Apple's rules-set in its California 
headquarters-govern its global supply chain, particularly its production activities in China. By tapping into internet firms with global operations, the MPAA and Internet Watch Foundation are able to carry out worldwide enforcement campaigns against the unauthorised downloads of movies and the distribution of child pornography.

The same characteristics that enable non-state regimes to be flexible and responsive to changes in circumstance can impede due-process mechanisms. Appeals processes may be inadequate or difficult to navigate and actors may impose sanctions based on suspicion, not proof, of wrongdoing. Regimes' participants may use technology to identify and target potentially suspicious behaviour, which raises challenges of wrongful identification and mass policing of legitimate activities and innocent people. The Internet Watch Foundation, for example, compiles a blacklist of websites suspected of being involved in distributing child pornography and instructs the internet firms participating in its program to block all sites on the list. However, blacklists can-and doincorrectly block legitimate content and thereby thwart legal activities. The criteria used to blacklist websites and the process for doing so are often closely guarded secrets, as is the case with the Internet Watch Foundation, which also blocks examination by outsiders of websites it blacklists (see Laidlaw 2012). Regulatory efforts based on secretly drafted criteria and unobservable processes raise significant problems in relation to accountability and legitimacy.

\section{Conclusion}

As transnational non-state regulatory regimes comprise a broad array of actors, rules, arrangements, strategies and interests, it is important to examine each regime's constituent components. An important element of this analysis is to explore the nature of the regime's authority, whether actors invoke moral, technical or discursive authority, or how they draw on their resources to wield structural authority. Further, it is necessary to determine how actors set rules: do they primarily use statutory laws or contracts, non-legally binding mechanisms or some combination of these? Related to this, one must examine the degree to which the regime relies on the state or its structures. State actors may play significant roles in supporting, facilitating or even directly constructing the regime, depending on the degree to which the state's interests align with those of the regime. As states recognise non-state regimes, they legitimise the 
regime and its activities. Not all states, however, have equal influence over transnational non-state regimes, nor can all non-state actors equally shape public policymaking. Such regimes often follow a global NorthSouth pattern in which rules are set by actors in the global North and then exported worldwide. The three regimes explored throughout the chapter-Apple's supply-chain program, the Internet Watch Foundation and the MPAA's antipiracy campaign-echo this global North-South configuration. These examples demonstrate the importance of state actors in facilitating and, in certain cases, directly shaping non-state regulation, even coercively pressuring non-state actors' participation. Given the diversity of transnational non-state regimes and the important issues they regulate, this is a fertile area for future research.

\section{Further reading}

Eberlein, B, Abbott KW, Black, J, Meidinger, E and Wood, S 2014. 'Transnational business governance interactions: Conceptualization and framework for analysis', Regulation E Governance 8(1): 1-21. doi.org/10.1111/rego.12030.

Scott, C 2012. 'Beyond taxonomies of private authority in transnational regulation', German Law Journal 13(12): 1329-38.

Zumbansen, P 2011. 'Neither "public" nor "private", "national" nor "international": Transnational corporate governance from a legal pluralist perspective', Journal of Law and Society 38(1): 50-75. doi. org/10.1111/j.1467-6478.2011.00534.x.

\section{References}

Apple 2014. Supplier Responsibility 2014 Progress Report. Cupertino, CA: Apple Inc. Available at: apple.com/au/supplier-responsibility/pdf/ Apple_SR_2014_Progress_Report.pdf.

Apple Press Info 2012. 'Fair Labor Association begins inspections of Foxconn', Press release, 13 February, Apple Inc., Cupertino, CA. Available at: apple.com/pr/library/2012/02/13Fair-LaborAssociation-Begins-Inspections-of-Foxconn.html.

Avant, DD, Finnemore, M and Sell, SK (eds) 2010. Who Governs the Globe? Cambridge: Cambridge University Press. 
Brandom, R 2014. 'Project Goliath: Inside Hollywood's secret war against Google', The Verge, 12 December. Available at: theverge. com/2014/12/12/7382287/project-goliath.

Cafaggi, F 2010. New Foundations of Transnational Private Regulation. Private Regulation Series-04. Florence: Robert Schuman Centre for Advanced Studies, European University Institute. Available at: cadmus.eui.eu/bitstream/handle/1814/15284/RSCAS_2010_53.pdf.

Cafaggi, F (ed.) 2012. Enforcement of Transnational Regulation: Ensuring Compliance in a Global World. Cheltenham, UK: Edward Elgar.

Cutler, AC, Haufler, V and Porter, T 1999. Private Authority and International Affairs. Albany, NY: State University of New York Press.

Dashwood, HS 2012. The Rise of Global Corporate Social Responsibility: Mining and the Spread of Global Norms. Cambridge: Cambridge University Press. doi.org/10.1017/CBO9781139058933.

Drahos, $\mathrm{P}$ and Braithwaite, J 2002. Information Feudalism: Who Owns the Knowledge Economy. Oxford: Oxford University Press.

Eberlein, B and Grande, E 2005. 'Beyond delegation: Transnational regulatory regimes and the EU regulatory state', Journal of European Public Policy 12(1): 89-112. doi.org/10.1080/1350176042000311925.

Fuchs, D 2007. Business Power in Global Governance. Boulder, Colo.: Lynne Rienner.

Fuchs, D and Kalfagianni, A 2010. 'The causes and consequences of private food governance', Business and Politics 12(3): 1-36. doi. org/10.2202/1469-3569.1319.

Graz, JC and Nölke, A 2008. 'Introduction: Beyond the fragmented debate on transnational private governance', in JC Graz and A Nölke (eds), Transnational Private Governance and its Limits. New York: Routledge, pp. 2-26.

Hall, PA 1993. 'Policy paradigms, social learning, and the state: The case of economic policymaking in Britain', Comparative Politics 25(3): 275-96. doi.org/10.2307/422246.

Internet Watch Foundation 2013. Internet Watch Foundation Annual and Charity Report 2013. Cambridge: Internet Watch Foundation. Available at: iwf.org.uk/accountability/annual-reports/2013-annualreport. 
Laidlaw, E 2012. 'The responsibilities of free speech regulators: An analysis of the Internet Watch Foundation', International Journal of Law and Information Technology 20(4): 312-45. doi.org/10.1093/ ijlit/eas018.

Levi-Faur, D 2005. 'The global diffusion of regulatory capitalism', The Annals of the American Academy of Political and Social Science 598(1): 12-32. doi.org/10.1177/0002716204272371.

Levi-Faur, D 2013. "The odyssey of the regulatory state: From a "thin" monomorphic concept to a "thick" and polymorphic concept', Law E Policy 35(1-2): 29-50. doi.org/10.1111/lapo.12000.

Meidinger, E 2002. 'Forest certification as a global civil society regulatory institution', in E Meidinger, C Elliott, and G Oesten (eds), Social and Political Dimensions of Forest Certification. Remagen-Oberwinter, Germany: Gupta Books, pp. 265-89.

Mügge, D 2006. 'Private-public puzzles: Inter-firm competition and transnational private regulation', New Political Economy 11(2): 177-200. doi.org/10.1080/13563460600655524.

Osborne, D and Gaebler, $\mathrm{T}$ 1992. Reinventing Government: The Entrepreneurial Spirit is Transforming the Public Sector. New York: Plume.

Picciotto, S 2002. 'Introduction: Reconceptualising regulation in the era of globalisation', Journal of Law and Society 29(1): 1-11. doi. org/10.1111/1467-6478.00208.

Scott, C 2002. 'Private regulation of the public sector: A neglected facet of contemporary governance', Journal of Law and Society 29(1): 5676. doi.org/10.1111/1467-6478.00211.

Strange, S 1997. 'The retreat of the state: The diffusion of power in the world economy', International Journal 52(2): 366-9.

Tusikov, N 2016. Chokepoints: Global Private Regulation on the Internet. Oakland, CA: University of California Press.

Underhill, GRD 2003. 'States, markets and governance for emerging market economies: Private interests, the public good and the legitimacy of the development process', International Affairs 79(4): 755-81. 
This text is taken from Regulatory Theory: Foundations and applications, edited by Peter Drahos, published 2017 by ANU Press, The Australian National University, Canberra, Australia. 